\title{
Global Integration in the Banking Industry
}

Allen N. Berger, of the Board's Division of Research and Statistics, and David C. Smith, of the Board's Division of International Finance, prepared this article. Jennifer Judge provided research assistance.

Many observers believe that significant global integration is under way in the banking industry and that, in the coming years, individual banks will expand their reach into many countries. Likewise, these observers expect that many national banking markets will develop large foreign components; as that happens, the nationality of a bank in such a market will matter little to prospective customers. ${ }^{1}$

These forecasts are based on the observation that, over the past two or three decades, many nations have removed important regulatory barriers to international banking. Advances in technology also now allow financial institutions to manage larger information flows across more locations and to evaluate and manage risks at lower costs than ever before. Together, these developments have reduced the costs of supplying banking services across borders. At the same time, growth in the international activities and trade of multinational corporations has increased the demand for services from financial institutions that operate across borders.

Despite these developments, the banking industry appears today to be far from globally integrated, particularly in industrialized countries. For example, the foreign share of bank assets in most industrialized countries remains at or below 10 percent. And although bank consolidation has been intense within industrialized countries, mergers and acquisitions across the borders of these countries have been much less common. ${ }^{2}$

Note. Much of the analysis in this article is based on Allen N. Berger, Qinglei Dai, Steven Ongena, and David C. Smith, "To What Extent Will the Banking Industry Be Globalized? A Study of Bank Nationality and Reach in 20 European Nations," Joumal of Banking and Finance, vol. 27 (March 2003), pp. 383-415. The authors of the present article thank David Birks for making available the "GlobalCash-Europe96" data and Gregory P. Nini for writing the program that examines syndicated loans.

1. For example, Paul R. Krugman and Maurice Obstfeld, in their International Economics: Theory and Policy, 5 th ed. (Reading, Mass.: Addison-Wesley, 2000), state that "one of the most pervasive features of the commercial banking industry of the $1990 \mathrm{~s}$ is that banking activities have become globalized" (p. 649).

2. For the 10 percent figure, see Stijn Claessens, Asli DemirguçKunt, and Harry Huizinga, "How Does Foreign Entry Affect the
To evaluate more closely the extent to which banking is becoming globally integrated, we study the nationality and international reach of banks that provide financial services across Europe to affiliates of multinational corporations. We examine these affiliates because they are among the customers most likely to demand the services of international banks, and we focus on Europe because barriers to financial integration have been extensively reduced on that continent. A finding that banking integration has advanced little even under such favorable conditions would cast doubt on the prospects for the globalization of banking more generally.

We rely mostly on an extensive, carefully conducted 1996 survey of the short-term banking practices of more than 2,000 European affiliates of multinational corporations. Perhaps surprisingly, we find that close to two-thirds of these affiliates choose a bank headquartered in the nation in which they are operating (a host-nation bank) rather than a bank from their home country or a third nation. Moreover, having chosen a host-nation bank, an affiliate is more likely to select a bank limited to local or regional operations rather than a large bank with global reach.

We also examine time-series data that might reveal the degree to which global integration has increased over the past decade. These data cover European syndicated loans, the ratio of domestic private bank claims to total (domestic plus foreign) bank claims, and the dispersion of nonfinancial goods prices across Europe. In brief, the time-series data show a picture for the current period that is not substantially different from that at the time of the 1996 survey.

These results are consistent with the idea that affiliates value host-nation banks over others because host-nation banks better understand their own market and may possess superior information about local nonfinancial suppliers and customers. Our results also imply that affiliates that have chosen host-nation banks value the more customized and relationshipbased services offered by banks with local or regional reach, as opposed to the broad-based services offered by a host-nation bank that has global reach.

Domestic Banking Market?" Journal of Banking and Finance, vol. 25 (May 2001), table 1, p. 896. For mergers and acquisitions across borders, see Group of Ten, Report on Consolidation in the Financial Sector (Basel, Switzerland: Bank for International Settlements, 2001). 
Our findings suggest that even as economic forces push toward globalization, the high demand for hostbased expertise by bank customers, coupled with the competitive advantages that host-nation banks have in providing this expertise, implies that many banking services could very well remain local. In other words, banking markets need not become much more integrated as the globalization of other economic sectors continues.

\section{FOCUS ON EUROPE}

Europe is an ideal setting for studying international integration because its countries have taken a number of steps to reduce regulatory barriers to cross-border banking. These steps are known collectively as the "single market" program. ${ }^{3}$ Under this program, the European Commission and the European Union (EU) Council of Ministers established directives intended to guarantee equal regulatory treatment of foreign banks by national authorities, unfettered provision of financial services across borders, home-country control of bank supervision, and home-country implementation of bank solvency requirements. ${ }^{4}$ The EU Council also passed regulations to liberalize crossborder capital flows and harmonize regulations across member countries that cover capital adequacy, credit exposure, and banks' participation in nonfinancial activities. Most of these directives had been implemented by the mid-1990s. In 1999, eleven members of the EU also entered into the European Monetary Union (EMU) and began to trade in a single currency, the euro.

The EU Council has as one of its goals the creation of a single, integrated banking market. An assumption behind such a goal is that cross-border competition fosters efficient, low-cost banking by allowing more efficient banks to move across borders and compete with less-efficient banks formerly protected by their nation's borders. Competition forces the inefficient banks to either improve or to leave the

3. Jean Dermine, "Banking in Europe: Past, Present, and Future," in Vitor Gaspar, Philipp Hartmann, and Olaf: Sleijpen, eds., The Transformation of the European Financial System, Second ECB Central Banking Conference (Frankfurt: European Central Bank, 2003) pp. 31-116.

4. Currently, the fifteen members of: the European Union (Austria, Belgium, Denmark, Finland, France, Germany, Greece, Ireland, Italy, Luxembourg, the Netherlands, Portugal, Spain, Sweden, and the United Kingdom) and the three additional nations of the European Economic Area (Iceland, Liechtenstein, and Norway) have agreed to abide by the bank-related directives.

5. The original EMU members are Austria, Belgium, Finland, France, Germany, Ireland, Italy, Luxembourg, the Netherlands, Portugal, and Spain. On January 1, 2001, Greece became the twelfth country to adopt the euro. market. As the lowest-cost producers of banking services expand across many borders, they drive prices closer to marginal costs.

Europe has other characteristics that support financial integration. The proximity of most of its countries to each other should keep cross-border transaction costs low. In addition, the countries of western Europe are technologically advanced. As of the early 1990 s, they were producing more science and engineering Ph.D.s than either the United States or Asia and were spending as much as the United States on nondefense-related research and development. ${ }^{6}$

Even within Europe, however, the evidence suggests that the integration of banking is advancing little, if at all. With the exception of the recent consolidation across the Nordic countries, bank merger and acquisition activity has been minimal across European borders. ${ }^{7}$

Remaining informal barriers in Europe could help explain this slow pace. One potential barrier is brand loyalty to local services. Observers often cite reluctance by bankers in Europe to compete in foreign countries in which they believe that loyalty to local products is strong. So, for example, Swiss banks do little business in Germany, and German banks do little business in Switzerland. Yet German and Swiss banks both have a strong presence in the United States, where loyalty to local brands is viewed as less of an issue. National government policies could also inhibit cross-border competition. For instance, despite an explicit commitment to a level playing field, European governments often promote the expansion of their own nations' banks through tax breaks, subsidies, guarantees, and direct ownership. ${ }^{.}$

We argue that such barriers are not the only explanation for the observed lack of integration in Europe. The slow pace of integration could result in large part from competitive advantages enjoyed by host-nation banks.

6. National Science Foundation, Human Resources for Science \& Technology: The European Region, NSF 96-316 (Arlington, Va: NSF, 1996). Organisation for Economic Co-operation and Development, OECD Science and Technology Indicators (Paris: OECD, 1995).

7. The Nordic countries are Denmark, Finland, Iceland, Norway, and Sweden. See Claudia M. Buch and Gayle L. Delong, "CrossBorder Bank Mergers: What Lures the Rare Animal?" Journal of Banking and Finance (forthcoming); Patrick Beitel and Dirk Schiereck, "Value Creation at the Ongoing Consolidation of: the European Banking Market," Institute for Mergers and Acquisitions, working paper; and Steven Ongena, Jason Karceski, and David C. Smith, "The Impact of Bank Consolidation on Commercial Borrower Welfare," International Finance Discussion Papers 679 (Board of: Governors of the Federal Reserve System, 2000).

8. Rafael La Porta, Florencio Lopez-de-Silanes, and Andrei Shleifer, "Government Ownership of Banks," Journal of Finance, vol. 57 (February 2002), pp. 265-301. 


\section{NATIONALITY AND REACH. OF BANKS}

In a frictionless banking market with no barriers to integration, commercial customers will select the bank that provides the price, quality, and mix of services that will best facilitate their business operations. Two potentially important criteria for a foreign affiliate's choice are the bank's nationality and reach.

Bank nationality refers to the country in which the bank is headquartered. Some affiliates might value banking services that require a detailed knowledge of the country in which the affiliate operates. Banks headquartered in the nation that hosts the affiliate will likely have an advantage in offering these services, which we term "host-based" expertise. So, for example, an affiliate of a U.S. corporation operating in Germany might choose a German bank because such a bank will best understand the culture, business practices, and regulatory conditions in Germany. The bank may even have unique access to information about German nonfinancial suppliers and customers.

Other affiliates might value a bank that offers "home-based" expertise - that is, an understanding of the home market of the affiliate's parent-because it is important to the affiliate to rely on a bank familiar with its home territory." Perhaps the bank already serves the parent corporation in the home country. Banks headquartered in the affiliate's home country should have an advantage in offering homebased expertise. A U.S. affiliate operating in Germany that values home-based expertise might then prefer a U.S. bank because of its advantage in offering such services.

Banks from third countries (that is, from neither the host nor the home country) may not have hostbased or home-based expertise, but they might competitively offer services in other dimensions valued by an affiliate. For instance, a U.S. corporate affiliate in Germany may value, say, a Dutch bank for a specialized service not offered by host- or homenation banks.

Bank reach refers to the size and geographic scope of the bank. Some affiliates may value a large, global bank that can offer a broad range of financial services, expertise within many foreign markets, superior risk diversification, and the ability to facilitate large deals. For the affiliate operating in Germany, this choice need not depend on bank nationality because the affiliate could choose a global German bank (for example, Deutsche Bank), a global U.S.

9. Berger, Dai, Ongena, and Smith, "To What Extent Will the Banking Industry Be Globalized?" refer to host-based expertise as "concierge" services and home-based expertise as "home cookin" services. bank (for example, Citibank), or a global third-nation bank (for example, the Dutch bank ABN AMRO). A different set of affiliates may prefer the advantages of a smaller bank that offers services in only a local area because such a bank is more likely to establish a close relationship with the affiliate and provide customized services. Such an affiliate that operates in Germany might select a German bank that has a local character and operates only in Germany or maybe even in only one part of the country. Still other affiliates may prefer a bank that blends international reach with local, personalized services. Such a bank's reach may be limited to a specific region or set of countries. So, a U.S. affiliate operating in Germany that prefers a blend of the far-reaching services of a global bank and the more personalized character of a local bank might choose an institution that confines itself to operating mainly on the European continent (for example, the Nordic-based banking concern Nordea).

In the absence of barriers, the extent of integration in the banking industry will depend on how customers value different banking services and the extent to which banks of a given nationality and reach can provide those services. Importantly, if customers place a high value on global services and have little value for host-based or home-based expertise, then we might expect to see an integrated banking industry, perhaps with a few global banks dominating markets around the world. Conversely, if customers value host-based expertise and place less value on global services, then we should observe limited banking industry integration. Thus, depending on the services valued by bank customers, we could have a world with extensive integration or one with little integration.

In the next section, we use the concepts of bank nationality and reach to examine our primary data set.

\section{THE 1996 SURVEY}

Our main source for connecting foreign affiliates of multinational corporations with their banks is "GlobalCash-Europe96," a survey of the short-term banking services provided to large, nonbank corporations. ${ }^{10}$ The survey was conducted in 1996 across twenty European nations by The Bank Relationship Consultancy and the School of Management at the

10. The objective of the survey is to gather information on the cash management practices of corporations. However, the European usage of "cash management" covers virtually all short-term banking services. 
1. Banks in the 1996 sample that are defined as having global reach

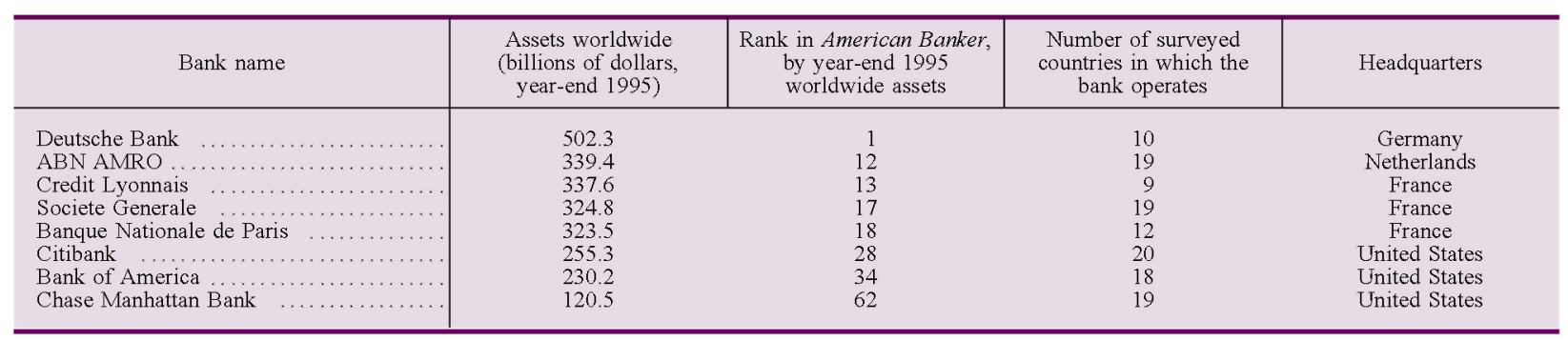

NoTE. Banks with global reach are defined as those that operate in at least nine of twenty European nations and had at least $\$ 100$ billion in worldwide assets as of year-end 1995 .

University of Bath, in the United Kingdom. ${ }^{11}$ Shortterm banking services include lending, deposittaking, liquidity management, foreign exchange management, and other financial services that have a time horizon of less than one year. A foreign affiliate of a corporation can take the form of a subsidiary, branch office, sales office, manufacturing plant, or some other related entity that requires banking services within a given country.

Responses to the survey were obtained from 1,129 corporations. These corporations had a total of 2,118 foreign affiliates operating in twenty countries in Europe, or about two affiliates per corporation. The parent corporations of most of these affiliates were headquartered in Europe, although 24 percent were headquartered outside Europe, mostly in the United States.

The survey asked corporations to identify the banks their foreign affiliates used for short-term banking services within each of the twenty countries. ${ }^{12}$ The nationalities of the sample banks named by the respondents were obtained from Fitch IBCA, a database containing information on the ownership structure of banks. Each bank subsidiary was assumed to take on the nationality and reach of its parent. Under this assumption, 255 banks provided short-term banking services for the 2,118 affiliates.

For each affiliate-bank observation, we identified the bank's nationality and reach. For nationality, banks are classified as either host-nation, home-

11. For a detailed description of the survey, see Steven Ongena and David C. Smith, "What Determines the Number of Bank Relationships: Cross-country Evidence," Journal of Financial Intermediation, vol. 9 (January 2000), pp. 26-56.

12. A respondent could identify up to two banks for each country-a "primary" and "secondary" bank. To avoid biases associated with double counting, we report all sample statistics using only the affiliate's primary bank choice. Berger, Dai, Ongena, and Smith, "To What Extent Will the Banking Industry Be Globalized?" find that the results reported here are not altered by use of an alternative definition that includes a secondary bank.
SourCE. Allen N. Berger, Qinglei Dai, Steven Ongena, and David C. Smith, "To What Extent Will the Bankıng Industry Be Globalızed? A Study of Bank Nationality and Reach in 20 European Nations," Journal of Banking and Finance, vol. 27 (March 2003), table 1, p. 391

nation, or third-nation banks. A host-nation bank is headquartered in the country in which the affiliate operates, a home-nation bank is headquartered in the same country in which the affiliate's parent is headquartered, and a third-nation bank is headquartered in neither the home nor host country.

For reach, banks are classified as global, regional, or local. Global banks are defined to have the widest reach. They provide services to the affiliates in at least nine of the twenty European nations from which respondents were drawn and have at least $\$ 100$ billion in consolidated assets as of year-end 1995. Local banks are defined to have the narrowest reach, providing services to the affiliates in the European nation of their headquarters only and having consolidated assets of less than $\$ 100$ billion. By definition, all local banks serve only as host-nation banks. Finally, regional banks are defined to have intermediate reach. They operate in more than one country or have more than $\$ 100$ billion in assets; but they operate in too few countries, or are too small, to be a global bank. Of the 255 banks in our sample, 8 are global, 73 are regional, and the remaining 174 are local.

By their nature, the bank reach classifications are somewhat arbitrary and Eurocentric. For instance, banks that have a strong European presence but do not operate outside of Europe could be classified as "global" under our system. Nevertheless, all eight banks are generally recognized as large, global banks (table 1). The findings are materially unchanged when the dividing lines between global and regional banks and between regional and local banks are altered. Overall, we are confident that the results are not an artifact of our definition of bank reach.

With respect to bank nationality, we find that nearly two-thirds of all affiliates (66 percent) use a bank headquartered in the host nation for their shortterm banking services (table 2). The remaining affiliates split evenly between using a home-nation bank (18 percent) and a third-nation bank (17 percent). 
2. Distribution of bank nationality and bank reach, by host nation, 1996

Percent except as noted

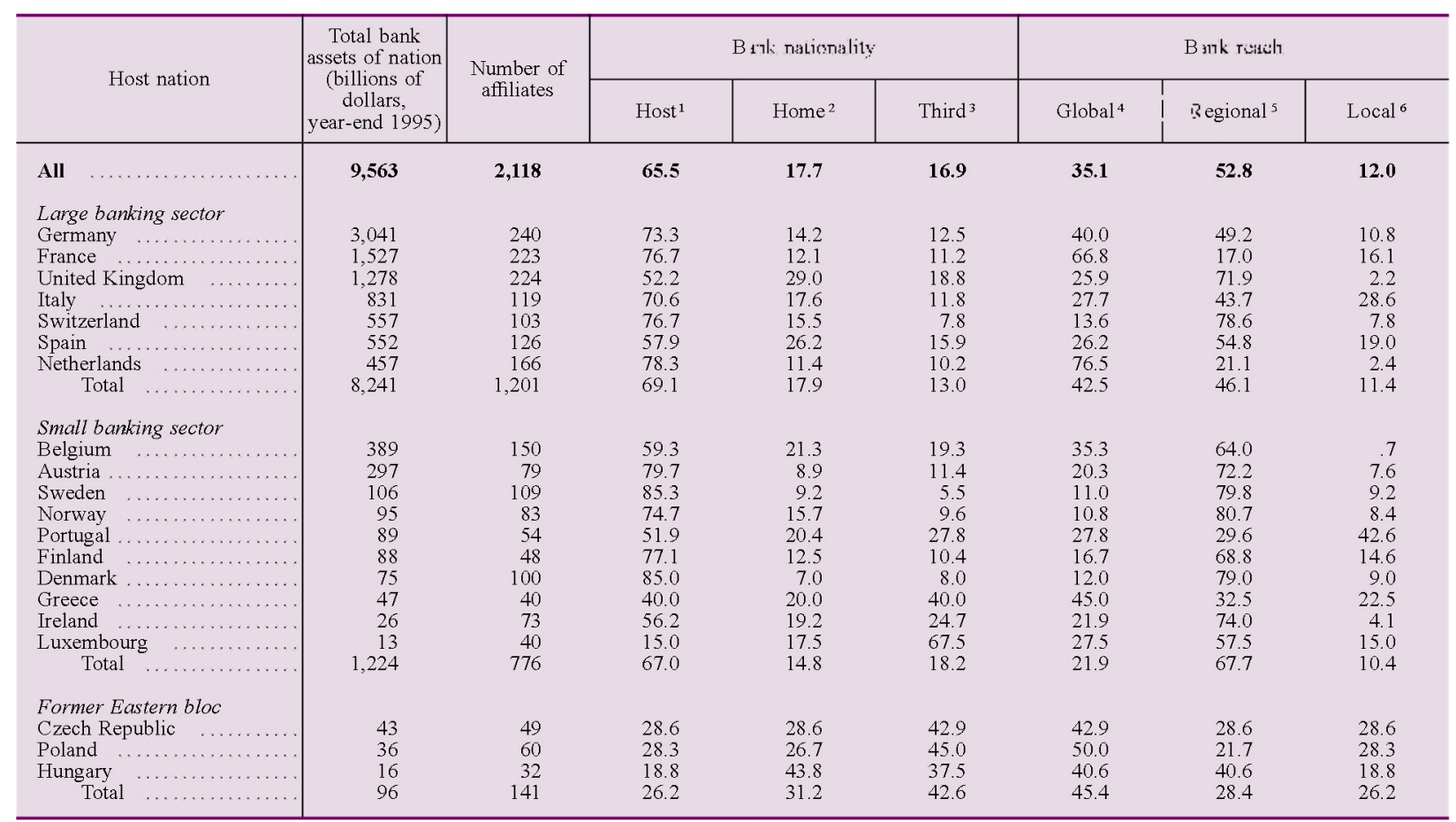

NotE. Banks are those chosen by affiliates of multinational corporations operating in twenty European countries and surveyed in 1996. The banks provide short-term banking services to the affiliates that selected them. Components may not sum to totals because of rounding.

1. A host-nation bank is headquartered in the nation in which the affiliate operates.

2. A home-nation bank is headquartered in the same nation in which the affiliate's parent is headquartered.

3. A third-nation bank is headquartered in neither the host nation nor the home nation.

This pattern suggests that preferences for host-based expertise are strong and tend to dominate bank selections. This finding also contrasts with the perception in much of the academic literature that foreign affiliates favor their home-nation banks. ${ }^{13}$

With respect to bank reach, about 35 percent of the affiliates choose global banks, 53 percent choose regional banks, and 12 percent choose local banks. These data suggest that while a vast majority of the foreign affiliates of multinational corporations prefer banks that span multiple nations (that is, global or regional banks), only about one-third choose global banks.

We also examine the distribution of bank nationality and reach within each of the twenty host countries, sorted by the total size of the nation's banking

13. For example, see Larry G. Goldberg and Anthony Saunders, "The Determinants of Foreign Bank Activity in the U.S.," Journal of Banking and Finance, vol. 15 (March 1981), pp. 17-32; and E.C. Kaplanis and Richard A. Brealey, "The Determination of Foreign Bank Location," Journal of International Money and Finance, vol. 15 (August 1996), pp. 577-97.
4. A global bank provides services to the affiliates in at least nine of the twenty European nations and had at least $\$ 100$ billion in worldwide assets as of year-end 1995 .

5. A regional bank is neither global (is in too few nations or is too small) nor local (is in too many nations or is too large)

6. A local bank provides services to the affiliates only in the European nation of the bank's headquarters and had worldwide assets of less than $\$ 100$ billion as of year-end 1995 .

SoURCE. Berger, Dai, Ongena, and Smith, "To What Extent Will the Banking Industry Be Globalized?" table 2, p. 392

sector and grouped into one of three categories: largebanking-sector nation, small-banking-sector nation, or former Eastern-bloc nation (table 2). The data show that bank nationality choice can differ greatly across industrialized host nations, particularly among small-banking-sector countries. For instance, only 15 percent of the affiliates operating in Luxembourg use a host-nation bank, whereas about 85 percent of those in Sweden do so. We separately consider the banking systems of the former Eastern-bloc nations because they tend to have legal and financial systems that are relatively new compared with those of western Europe. ${ }^{14}$ Only 26 percent of the affiliates operating in the former Eastern-bloc nations use a host bank; about 43 percent select a bank from a third nation. Thus, use of host-nation banks in the former Eastern-bloc nations is much less frequent than in the industrialized nations of western Europe.

14. The former Eastern-bloc countries in the sample are the Czech Republic, Hungary, and Poland. 
3. Distribution of bank nationality and bank reach, by home nation, 1996

Percent except as noted

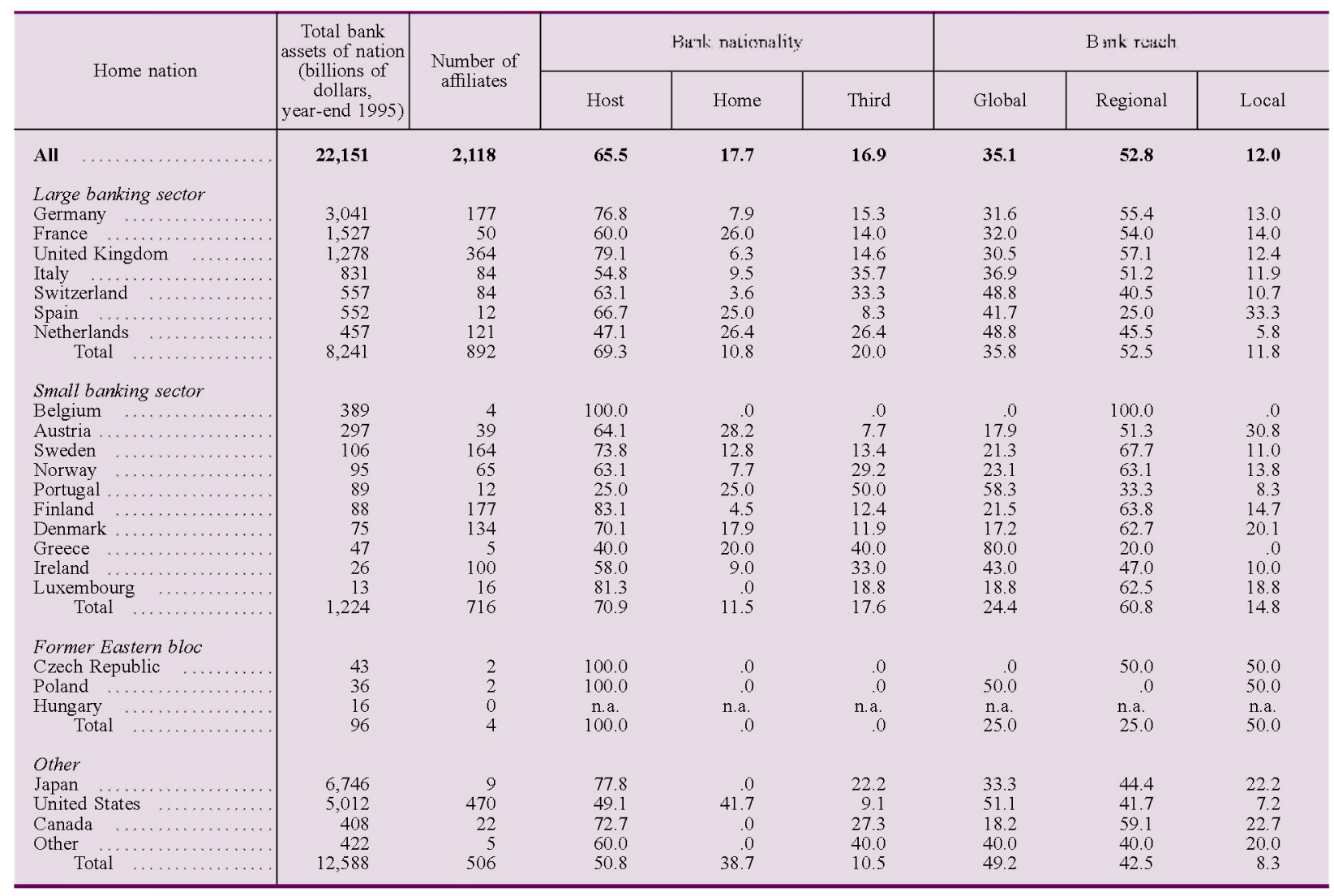

Note. See notes to table 2 .

n.a. Not applicable.

The data on bank reach also show considerable variation across host nations. Global banks are chosen relatively more frequently in large-banking-sector nations (43 percent) and in former Eastern-bloc nations (45 percent) than in small-banking-sector nations ( 22 percent). This observed pattern seems to indicate that global banks prosper best in markets open to bank competition (large-banking-sector nations) and in markets with less-established banking systems (former Eastern-bloc nations). Also notable is the variation in reach among the largebanking-sector nations. For example, about twothirds of the affiliates operating in France use a global bank; more than two-thirds of the affiliates operating in Switzerland and the United Kingdom use regional banks; and more than one-fourth of the affiliates operating in Italy use local banks.

We also examine the distribution of bank nationality and reach according to the home nation of the affiliate, including countries outside the twenty host European nations (table 3). Of the foreign affiliates with corporate headquarters in European countries with both large and small banking sectors, 70 percent select a host-nation bank and only about
11 percent opt for a home-nation bank. This result is surprising, given that many of the European corporations have large home-nation banks close by from which to choose. In fact, the only outlier home nation is the United States. Of the affiliates whose parents are headquartered in the United States, 42 percent choose home-nation banks, a rate much higher than that for affiliates from other countries. This finding could reflect the ability of U.S.-owned banks to operate relatively efficiently in foreign countries, consistent with the academic literature. ${ }^{15}$

Although bank nationality and reach are two distinct concepts, they can be related. For instance, we have already seen that banks with local reach have, by definition, host-nation nationality. Other dependencies may result from how banks with a given reach are distributed across countries. For example, some countries do not have a global bank headquartered within their borders. Banks in these countries

15. See Allen N. Berger, Robert DeYoung, Hesna Genay, and Gregory F. Udell, "Globalization of Financial Institutions: Evidence from Cross-Border Banking Performance," in Robert E. Litan and Anthony Santomero, eds., Brookings-Wharton Papers on Financial Services (Washington: Brookings Institution Press, 2000), pp. 23-158. 
Diagram 1. Distribution of bank nationality and bank reach in a two-stage decision tree

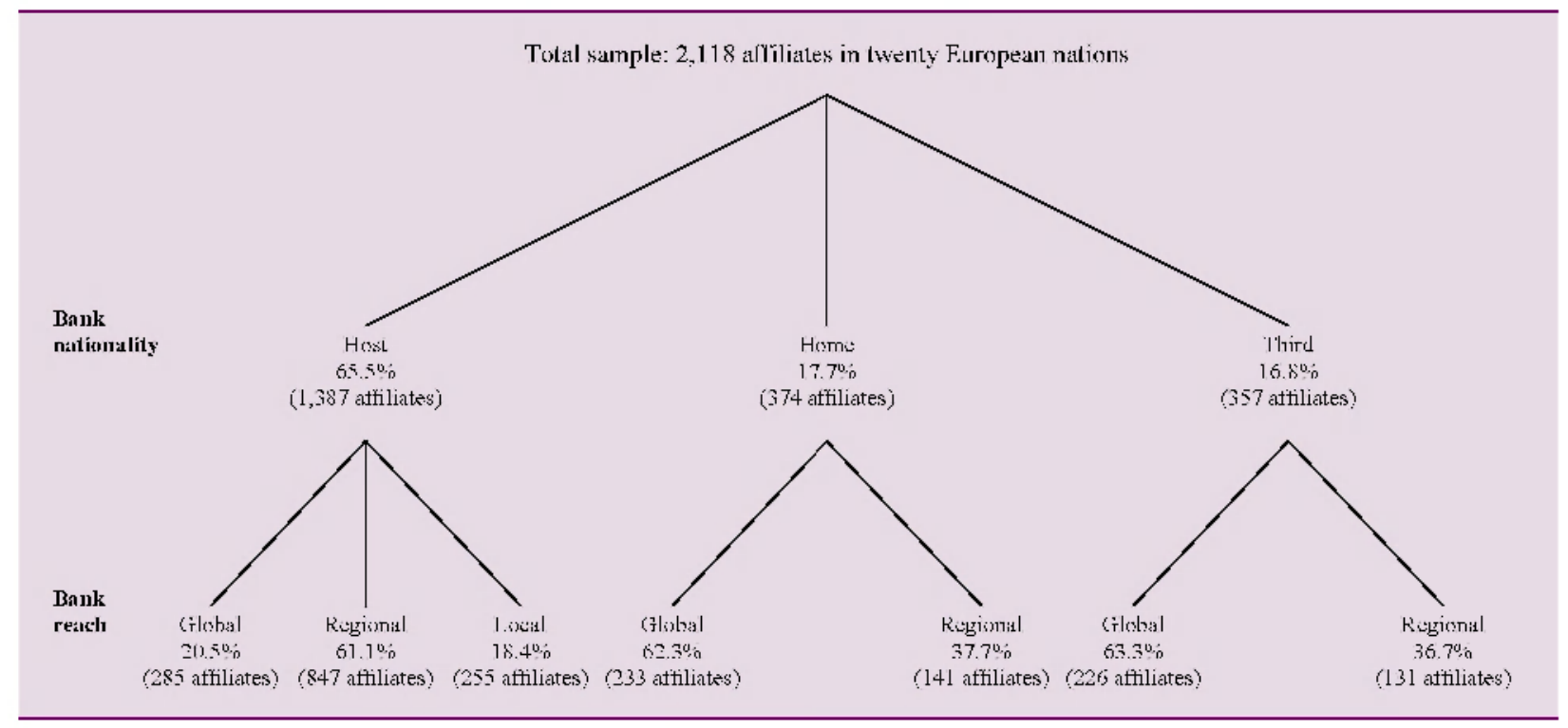

Note. See notes to table 2. By definition, a local bank does not arise as a second-stage choice when an affiliate chooses a home-nation or third-nation bank.

cannot offer both host-based expertise and global services to affiliates that value such a combination. Likewise, banks from these countries cannot jointly offer home-based and global services to affiliates of native corporations operating abroad. Finally, some banking systems may be too new or undeveloped to offer competitive banking services at even a local level.

We study potential dependencies between bank nationality and reach by assuming that bank reach depends first on the selection of bank nationality. We reason that, in the absence of barriers to integration, a bank's reach will be limited by the extent to which customers value cross-border banking relations. For example, in the extreme case that all bank customers selected host-nation banks for all of their services, there would be no need for banks with global reach.

A two-stage decision tree illustrates our framework (diagram 1). In the first stage, an affiliate decides on bank nationality; in the second stage, it chooses bank reach. Note that by definition, a local bank does not arise as a second-stage choice when an affiliate chooses a home-nation or third-nation bank in the first stage. At the nodes of the top branches of the tree, we report the sample frequencies for selecting a host-nation, home-nation, and third-nation bank, while at the bottom branch nodes, we report the sample frequencies for selecting a global, regional, and local bank given the prior choice of bank nationality.
As shown earlier, almost two-thirds of the affiliates use host-nation banks over home- and third-nation banks (table 2), a pattern consistent with strong hostbased expertise. Affiliates' choices for bank reach differ greatly, depending on bank nationality (diagram 1). After selecting a host-nation bank, about 21 percent of the affiliates use a global bank. By comparison, of affiliates that select either a homenation or third-nation bank, about 63 percent use a global bank. In other words, affiliates tend to use banks with global reach once they choose a homenation or third-nation bank, but they tend to use a regional or local bank once they choose a host-nation bank.

One aspect of the data that could be driving these patterns is that, as of 1996, only three host nationsFrance, Germany, and the Netherlands - had a global bank headquartered within their borders. That is, affiliates choosing a host-nation bank in any of the other seventeen nations in our sample could not also select a global bank. This limitation could simply reflect an equilibrium outcome - that is, the demand for global services within these countries is not great enough to induce a host-nation bank to expand its reach globally or to induce an existing global bank to move its headquarters to one of these countries. Alternatively, this outcome could reflect supply conditions in the host nation.

We look more closely at Germany to gain some insight into how the distribution of bank choices 
Diagram 2. Distribution of bank nationality and bank reach in Germany in a two-stage decision tree

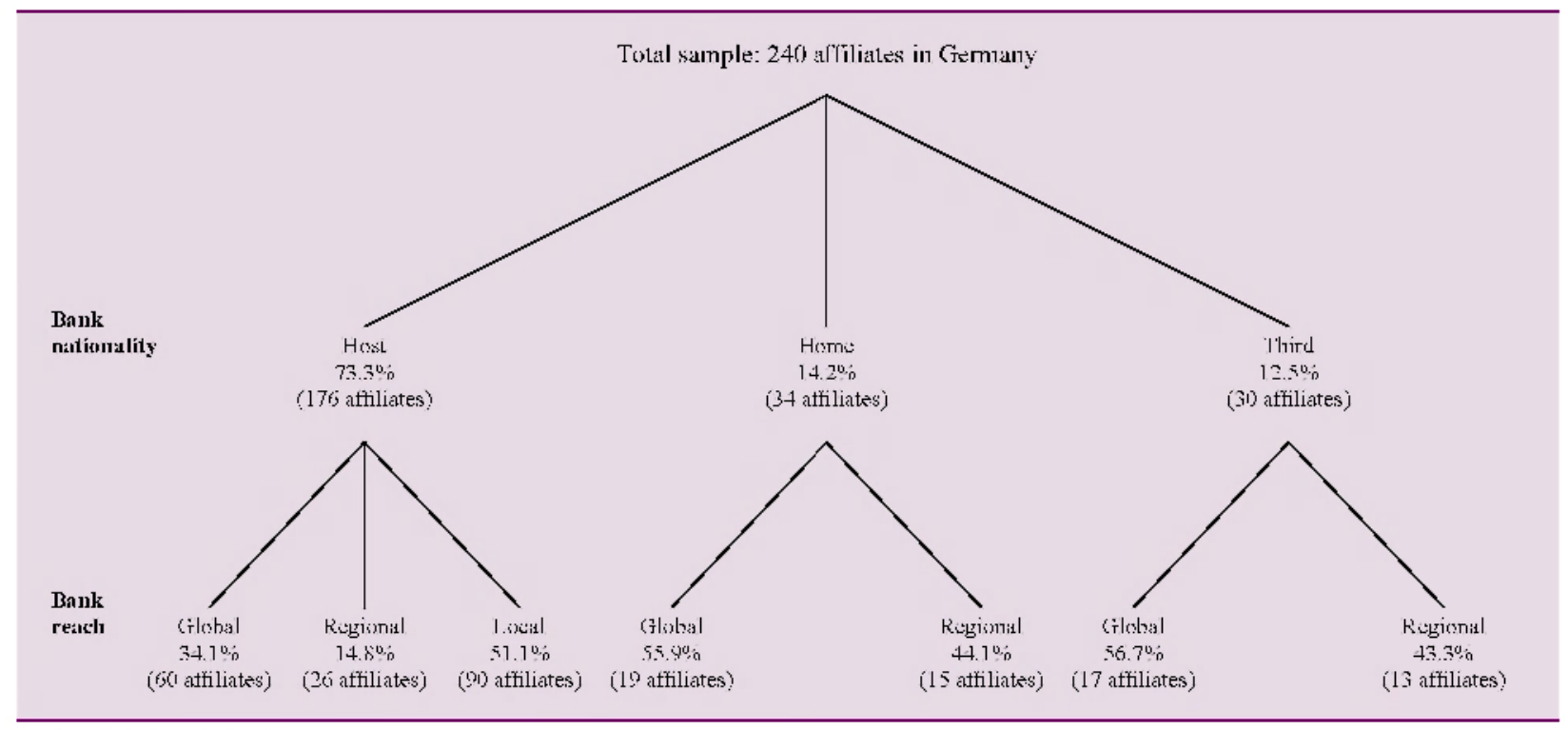

Note. Sü noles lis diagram 1.

might differ in a market in which all types of banks are available (diagram 2). Germany not only has a host-nation bank that is global (Deutsche Bank), but it also has three strong nationwide systems of local and regional commercial banks from which affiliates may choose: the Landesbanken (state banks), Sparkassen (savings banks), and Hypothekbanken (building societies).

The German data in diagram 2 suggest that the supply conditions alone do not create the patterns shown in diagram 1. A substantial proportion of the foreign affiliates operating in Germany still select a host-nation (that is, German) bank for their banking services. More important, if they choose a German bank, affiliates choose a regional or local bank over a global bank by a two-to-one margin; whereas, if they choose a home-nation or third-nation bank, most affiliates then choose a global bank.

The cross-country variation in bank nationality and reach was analyzed more formally using a regression model that attempted to control for the demand and supply factors within host nations, the geographic, cultural, and financial differences between host and home nations, and the attributes of a foreign affiliate's parent corporation. ${ }^{16}$ The regression analysis confirmed the importance of host-nation-based expertise in the choice of bank. An additional finding was that host-nation banks are less likely to be chosen in the former Eastern-bloc countries, and home-nation banks typically fill the void left by the host-nation

16. Berger, Dai, Ongena, and Smith, "To What Extent Will the Banking Industry Be Globalized?" banks in these countries. We speculate that the banking systems within these countries are not yet developed enough to offer competitive host-based expertise.

One limitation of the 1996 survey evidence is that it offers only a "snapshot" of the provision of banking services rather than a picture of the evolution of banking markets over time. Moreover, the snapshot was seven years ago; significant integration could have occurred since that time.

\section{A LOOK AT THE TTME-SERIES DATA}

We begin our time-series analysis with two measures of banking industry integration for the period from 1992 to 2002. The first measure is the proportion of syndicated loans that host-nation banks provide to European affiliates of multinational corporations. That is, we start with the same types of affiliates as examined in the previous section, but we now track the nationality of those banks that provide syndicated loans to the affiliates.

The syndicated loan market is a popular mechanism for extending loans to medium-sized and large borrowers and is often thought to be the most globally integrated sector of the banking industry. Our measure is constructed from Loanware, a database that tracks syndicated loan agreements from around the world. ${ }^{17}$ For the $1992-2002$ period, we review

17. Loanware is a product of Dealogic, Ltd. A syndicated loan agreement is a loan contract between a borrower and a group of banks, typically headed by a "lead" or "arranging" bank or group of banks. 
1. Indicators of banking market integration in Europe, 1992-2002

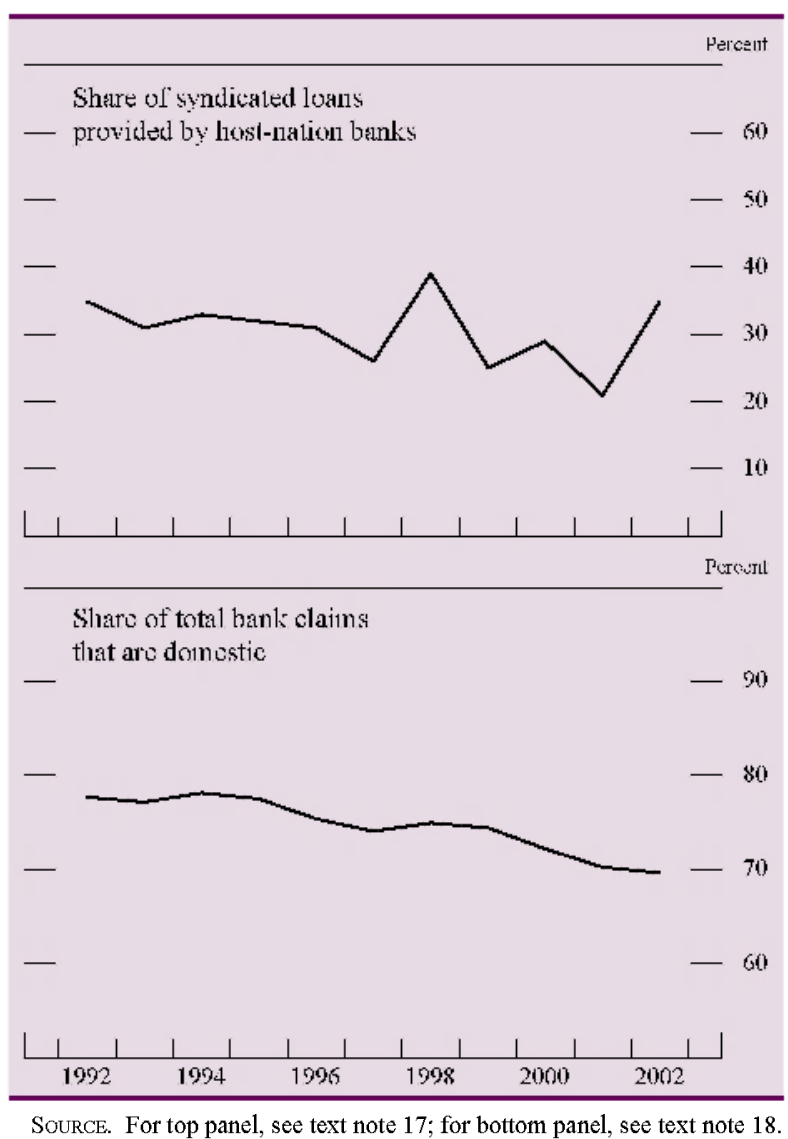

1,556 syndicated loans to foreign affiliates of multinational corporations operating in Europe.

The degree of integration as measured by the proportion of syndicated loans financed by host-nation banks did not increase over the past decade (chart 1). In 1992, host-nation banks financed 35 percent of the syndicated loans; in 2002, they financed the same proportion. Since 1996, the proportion of host-nation banks financing syndicated loans has fluctuated between 39 percent and 21 percent. Thus, the syndicated loan data provide no evidence to suggest that the level of bank integration has changed much since the 1996 survey.

The syndicated loan data suffer from a potential drawback. If the syndicated loan market was already fully integrated in 1992, then one might not expect it to change much over the decade. Indeed, we see that by 1992 foreign banks (home- and third-nation banks) already covered roughly two-thirds of the loans provided to foreign affiliates (chart 1, top panel), which might be close to full integration.

Another measure of integration that provides a more general assessment of changes through time is the share of total private bank debt claims (domestic and foreign) that are claims on domestic customers. This measure is calculated for banks residing in twelve countries in western Europe (Austria, Belgium, Denmark, France, Germany, Ireland, Italy, the Netherlands, Spain, Sweden, Switzerland, and the United Kingdom), plus Canada, Japan, and the United States. ${ }^{18}$

We interpret a decline in the share of domestic bank claims to total bank claims as an increase in the level of integration. The proportion has fallen somewhat over the past decade (chart 1 , bottom panel). It hovered around 78 percent from 1992 through 1995 and then began to decline slowly. By 2002 , the proportion had fallen to 70 percent. This decrease indicates that banks have increased their foreign claims over the past decade slightly faster than the rate at which they expanded their domestic claims.

We provide one more piece of time-series evidence on the progress of integration, and that is the pace of price convergence across countries. John Rogers uses a comprehensive and detailed set of prices for 139 nonfinancial consumer goods in twenty-five European cities from 1990 to 2001 to measure the speed at which prices converged as barriers to cross-border trade were diminished within Europe. ${ }^{10}$ Rogers compares the dispersion of prices in European cities, including a subset of cities within the eleven original countries of the EMU, to the dispersion of prices for a similar set of goods across cities within the United States. ${ }^{20}$ By 1996, the dispersion in prices across the European countries had narrowed significantly (chart 2). In fact, prices within the EMU countries had converged to a degree comparable to that observed in the United States. Most of the convergence occurred in the earlier part of the period, with little or no further convergence occurring after 1996.

In sum, the various sets of time-series data examined here suggest that little further integration has occurred in Europe since our sample was collected in 1996, although the BIS banks claims statistics

18. "Claims" refer to loans, notes, and equity claims that banks hold against customers. Foreign claims refer to claims on customers outside of a bank's resident country. Foreign claims are obtained from the Bank for International Settlements' locational statistises through www.bis,org. To avoid the double counting of claims against subsidiaries, we subtract local office claims from total foreign bank claims. Private domestic bank claims are from the International Monetary Fund's International Financial Statistics.

19. John H. Rogers, "Monetary Union, Price Level Convergence, and Inflation: How Close is Europe to the United States?" International Finance Discussion Papers 740 (Board of Governors of the Federal Reserve System, 2002).

20. Price dispersion is defined as the cross-city standard deviation of a product's price (calculated after normalizing the price by the average price of the product). 
2. Price dispersion for traded goods in Europe and the United States, 1990-2001

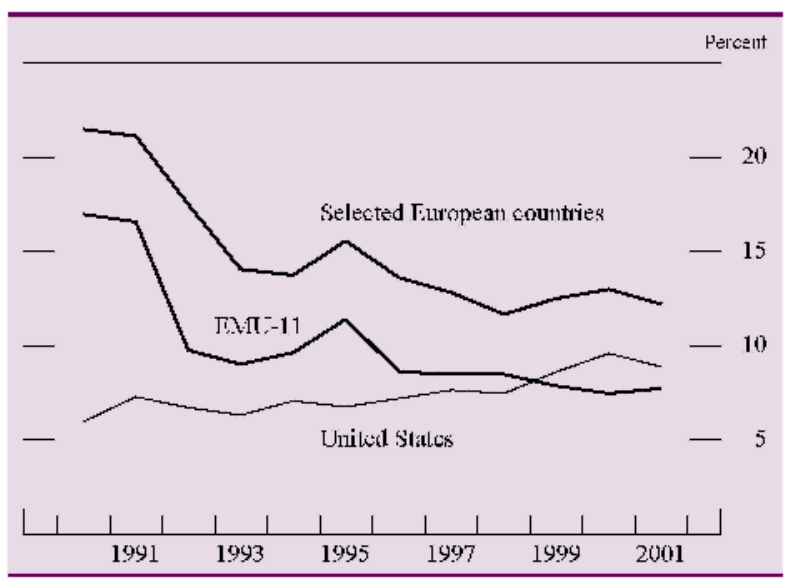

NoTE. The EMU-11 consists of Austria, Belgium, Finland, France, Germany, Ireland, Italy, Luxembourg, the Netherlands, Portugal, and Spain. The selected European countries are the EMU-11, the United Kingdom. Sweden, and Switzerland. For definition of price dispersion, see text note 20 . SOURCE. John H. Rogers, "Monetary Union, Price Level Convergence, and Inflation: How Close Is Europe to the United States?" International Finance Discussion Papers 740 (Board of Governors of the Federal Reserve System, 2002).

suggest that banks have expanded somewhat across borders since 1999 .

\section{SUMMARY}

The barriers to global integration in the banking industry have been significantly reduced over the past two decades. Among the contributing factors have been the lifting of regulatory restrictions on crossborder banking, technological advances that allow for better management of financial institutions across borders, and increases in nonfinancial activities that create demands for international banking services. Despite these reduced barriers, the integration of the banking industry in most developed countries has fallen far short of the expectations of many observers.

Some potentially powerful market forces based on the competitive advantages of domestic and foreign banks may help explain the lack of an advance in global banking. We argue that foreign banking organizations may be at significant competitive disadvantages in providing the price, quality, and mix of services that best suit bank customers, and that such disadvantages may limit the integration of the banking industry.

Our main findings, which are based on a 1996 cross-section of European affiliates of multinational corporations, suggest that almost two-thirds of these affiliates receive short-term banking services from a bank headquartered in the affiliate's host nation. This result is consistent with a strong host-based-expertise effect, in which host-nation banks have significant competitive advantages in understanding the culture, business practices, and regulatory conditions of the host nation. However, in the former Eastern-bloc nations, the data suggest that only about one-fourth of these same types of affiliates are served by hostnation banks. This finding is consistent with the possibility that host-nation banks in these nations are not equipped to provide the package of banking services that would give them an advantage over foreign institutions.

We also examine three sets of time-series data on the progress of integration in Europe from 1992 to 2002. The main purpose is to explore the possibility that our "snapshot" of banking as of 1996 might have predated significant advances in the integration of the European banking industry. We show data on the changes in (1) the proportions of the syndicated loan market that are underwritten by domestic banks, (2) the changes in the proportions of total bank claims that are held by domestic banks, and (3) the convergence of prices of consumer goods across Europe. These data suggest that, if anything, most of the effects of the reduced barriers had already occurred by 1996 .

Overall, the findings suggest that domestic banks possess some competitive advantages that may significantly limit the global integration of the banking industry. In industrialized nations, domestically based institutions appear likely to retain significant market shares for some financial services that could potentially be provided by foreign institutions, even when the barriers to bank integration have declined dramatically. In contrast, foreign banks may obtain much higher shares in some less-industrialized nations because of competitive advantages over domestic institutions that are less well developed. 